Paedagogia Christiana

2/28 (20II) - ISSN I505-6872

Piotr Krajewski*

Olsztyn

\title{
Edukacja ekologiczna w dokumentach Kościoła oraz prawie kanonicznym
}

Omawianie problemów ochrony środowiska życia człowieka mających swe umocowanie w ustawodawstwie Kościoła jest zadaniem niełatwym, ponieważ w Prawie Kanonicznym nie odnajdujemy żadnej normy, która bezpośrednio odnosiłaby do tego zagadnienia ${ }^{1}$. Co więcej, prawo to - jak dotychczas - nie sformułowało explicite etycznego obowiązku szanowania

* Dr Piotr Krajewski, adiunkt na Wydziale Prawa i Administracji Uniwersytetu Warmińsko-Mazurskiego w Olsztynie.

${ }^{1}$ Nie chodzi oczywiście o ingerowanie w autonomiczny porządek świata, ale o zaostrzenie poczucia odpowiedzialności za świat w sytuacjach, które Kościół uzna za konieczne ze względu na witalne interesy jednostki lub wspólnoty ludzkiej.

Z prawnego punktu widzenia, środowisko naturalne, pomimo mnogości określeń i elementów składowych, może być uważane jako zbiór dóbr naturalnych charakteryzujących się określoną autonomią i przeznaczeniem wynikającym z jedności stworzenia. Środowisko jako universitas jest przede wszystkim przedmiotem manifestującym obecność Boga i przedmiotem zainteresowania ze strony człowieka. Od strony prawnej, jako universitas rerum, stanowi zespół dóbr materialnych i niematerialnych złączonych aktem twórczym i funkcjonalnością przeznaczenia.

W obrębie prawa kanonicznego w tym universitas rerum można dostrzec autonomiczny prawny element odniesienia natury publicznej. Przyjmując ratio dyscypliny prawnej Kodeksu z 1983 roku, środowisko naturalne czasami można traktować jako autonomiczny przedmiot odniesienia prawa, a innym razem jako podmiot prawny, kiedy posiada charakterystyki wskazane w kan. 115 §3, szczególnie wtedy, gdy dotyczy to elementów odróżniających zarządzanie jednostkowe od kolegialnego. Wówczas można również mówić o istnieniu w prawie kanonicznym ,prawa środowiska”, obok ,prawa do środowiska”, w którym jako efekt tejże autonomii prawnej środowisko traktowane powinno być również podmiotowo. „Prawo ochrony środowiska" w doktrynie cywilistycznej łączy się z odmiennym traktowaniem go przez ekonomię, 
środowiska przyrodniczego. Wychodzi się z założenia, że ochrona środowiska naturalnego należy do zadań instytucji społeczno-politycznej, jaką jest państwo, a państwo realizuje swoje zadania poprzez obywateli. Wynika z tego, że obywatel-chrześcijanin nie może pozostawać obojętny wobec problemów bezpośrednio odnoszących się do całej wspólnoty obywateli, której jest przecież częścią. Taka postawa obywateli-wiernych to wyłącznie efekt odpowiedniej edukacji i wychowania, te z kolei, po części, wynikają z ,programu" nakreślonego prawem i doktryną.

\section{Kwestia ekologiczna w prawie kanonicznym}

Specyfika prawa kanonicznego ${ }^{2}$ polega między innymi na ścisłej łączności i zależności pomiędzy prawami człowieka i prawami wiernych w Kościele; inaczej mówiąc, prawa wiernych bazują na fundamentalnych prawach człowieka. Spośród wielu ustawodawca reguluje jedynie te, które mają określony związek z realizacją misji Kościoła. Jednym z nich jest szeroko rozumiane prawo do wynagrodzenia za pracę․ Wynagrodzenie to ma obejmować

która nie jest skłonna uznać środowiska jako wartości (Por. G. Di Plinio, Diritto pubblico dell'ambiente e aree naturali protette, Torino 1994, s. 31).

Odnosząc się do całości, środowisko słusznie widziane jest jako dobro publiczne zawierające w sobie wszelkie istnienie (materialne i niematerialne), przedmiot ochrony prawnej nie tylko ze względu na szczególne sytuacje prawne, które się z nim łączą, ale ze względu na konstytucjonalny charakter, jaki sobą prezentuje. W efekcie, również ze względu na konotacje personalistyczne, środowisku należy się właściwa ochrona prawna. Stwierdzenie to bezpośrednio potwierdza istnienie prawa człowieka do życia w warunkach godnych siebie. Nie chodzi tu jedynie o warunki społeczne, ale o środowisko naturalne.

Próby powiązania kwestii ekologicznej z prawem kanonicznym (kan. 115 §3) dokonał G. Dammacco (Por. G. Dammacco, Ambiente e diritti nell'ordinamento canonico, w: R. Sobański $\mathrm{i}$ in. (red.), Atti del Congresso Internazionale «I diritti fondamentali dell'uomo e dell'ambiente nei cambiamenti dell'Europa Centro-Orientale. Varsavia 2-4 giugno 1995», Warszawa 1995, s. 79-88), jednakże bliższa interpretacja określenia universitas rerum (por. E. Sztafrowski, Podręcznik prawa kanonicznego, Warszawa 1985, s. 227.) raczej nie wskazuje na elementy środowiska lub jego całość. Termin ten nie ma więc związku ze środowiskiem naturalnym, toteż w świetle kan. 115 §3 nie można mówić o kanonicznych aspektach ochrony środowiska. Wydaje się natomiast, że można doszukiwać się związku o charakterze pośrednim, na przykłąd poprzez pryzmat praw przynależnych osobie ludzkiej.

${ }^{2}$ Nawet jeżeli obszary prawa świeckiego i kanonicznego pozostają autonomiczne i niezależne, to w jednakowym stopniu dotyczą tego samego człowieka: obywatela i wiernego. Wzajemne przenikanie się dotyczy głównie terminologii, z terminologią łączy się treść, a więc i określone koncepcje prawne, albo określony sposób dostrzegania i oceny danego składnika rzeczywistości.

${ }^{3}$ Por. kan. 231 §1. Słuszne wynagrodzenie jest bliżej precyzowane w kan. $1286 \S 2$, gdzie mowa jest o konieczności zaspokojenia potrzeb własnych i rodziny. Potrzeby te, w wyniku suk- 
między innymi wypoczynek (por. LE 19) ${ }^{4}$ i to, jak się wydaje, wypoczynek w warunkach możliwie najlepszych. Sugeruje tu konieczność zapewnienia możliwie niezmienionego środowiska naturalnego, w którym człowiek może godnie i efektywnie wypoczywać, a ponieważ z dobrodziejstw natury korzystają wszyscy ludzie będący jednocześnie obywatelami i wiernymi, zagadnienia ochrony walorów naturalnych nie mogą być całkowicie obce ani Kościołowi, ani prawu kanonicznemu. Należy zauważyć, że podejście państwa do kwestii ekologicznych dokonuje się zawsze przez pryzmat ekonomii. Wszelkie działania w tym kierunku wypływają zawsze od człowieka, który jednocześnie jest odbiorcą swoich własnych inicjatyw. Oczywiście nie zawsze muszą to być korzyści materialne i wymierne ${ }^{5}$. Wydawałoby się, że obydwa systemy i w tym punkcie są zbieżne, ponieważ jednakowo mówią o konieczności i potrzebie wypoczynku, jednakże dla prawa świeckiego wypoczynek jest ważny przede wszystkim dla zwiększenia efektywności pracy. Natomiast ustawodawca kościelny, pozostawiając człowieka w centrum swojego zainteresowania, domaga się wypoczynku w warunkach umożliwiających mu realizację swojego człowieczeństwa ${ }^{6}$. W tej perspektywie Kościół i jego prawo spełniają jedynie rolę ,,interpretacyjną” polityki ekologicznej państwa. Wypada więc mówić tylko o pośrednim związku prawa kanonicznego z wieloaspektową tematyką ekologiczną. Być może właśnie ta komplementarność obydwu systemów skłoniła ustawodawcę kanonicznego do pominięcia bezpośredniego odniesienia się do kwestii ochrony środowiska, pozostawiając ją implicite rozważaniu i interpretacji normom świeckim. Nie jest to równoznaczne z tym, że Kościół pozostaje bierny wobec zagadnień społeczno-politycznych i ściśle łączących się z nimi aktualnych zadań

cesywnego poszukiwania znaczenia określenia, przybliżane są przez kolejnych papieży w kolejnych dokumentach obejmujących problemy socjalne. Warto pod tym kątem przeanalizować encykliki Leona XIII Rerum novarum (nr 17), Piusa XI Quadragesimo anno (nr 71), Jana XXIII Mater et Magistra (nr 71) oraz Konstytucję o Kościele w świecie współczesnym Soboru Watykańskiego II Gaudium et spes (nr 67).

${ }^{4}$ Por. Jan Paweł II, Encyklika o pracy ludzkiej Laborem exercens, w: Encykliki Ojca Świętego Jana Pawła II, t. I, Kraków 1996, s. 101-154.

${ }^{5}$ Przykładem jest tu wypoczynek na łonie natury czy praca w odpowiednich warunkach.

${ }^{6} \mathrm{~W}$ otoczeniu innych istot i natury ma możliwość skorygowania własnej wizji świata i relacji ze Stwórcą. Refleksja ta ukazuje brak konfliktu kompetencji obu porządków prawnych. Celem świeckiego prawa stanowionego jest rozwiązywanie konkretnych problemów i kształtowanie polityki ekologicznej. Zadaniem Kościoła jest między innymi dokonywanie etycznej interpretacji norm świeckich oraz formułowanie własnych norm, które w tej kwestii mogą mieć raczej charakter informacyjny niż sankcjonujący. Por. M. Sitek, Problemy ekologii w polityce prawnej i prawie Wspólnoty Europejskiej. Wkład do europejskiej kultury prawnej, Torun 1997, s. 147-148. 
utrzymania zasobów przyrodniczych. W tej funkcji dbałości o świat Kościół uczestniczy, wyrażając swą otwartość na wszelkie problemy ludzkości i rozwijanie relacji pomiędzy człowiekiem i otaczającą go rzeczywistością?

\section{Ekologia jako wyraz odpowiedzialności za środowisko życia czlowieka}

Współczesna ekologia stosunkowo niedawno dojrzała do analizowania od wieków zapomnianych już kwestii efektów oddziaływania człowieka na środowisko i miejsca człowieka we wszechświecie ${ }^{8}$. W nowym kontekście naukowym pojawił się dokument Kościoła katolickiego, w którym właściwie po raz pierwszy podjęto zagadnienia ekologiczne. Było to orędzie Pawła VI, skierowane do uczestników międzynarodowej konferencji poświęconej ochronie środowiska zorganizowanej przez ONZ w Sztokholmie ${ }^{9}$, w czasie której nakreślono również ONZ-towski program ochrony środowiska. Świadomość społeczności międzynarodowej, że nadużycia w jednym punkcie globu wywołują reperkusje w miejscach od niego oddalonych i prowadzą do zmiany jakości życia innych ludzi (często bez ich wiedzy lub winy) legła u podstaw stwierdzenia, że taka zależność musi dziś korespondować $\mathrm{z}$ współodpowiedzialnością ${ }^{10}$, gdyż środowisko naturalne jest własnością całej ludzkości, jej dziedzictwem ${ }^{11}$.

${ }^{7}$ Por. R. Sobański, Kościót jako podmiot prawa, Warszawa 1994, s. 175.

${ }^{8}$ Po rewolucji naukowej, wraz z Oświeceniem, które ugruntowało bezwarunkową wiarę w umiejętność panowania człowieka nad naturą, nie były analizowane i oceniane jako problem. Ekologia sprowadziła istotę ludzką do poziomu faktu w serii procesów naturalnych. Por. L. Postiglione, Per una cultura ecologica. Istanze scientifiche e religiose, „Rassegna di Teologia” 3 (1999), s. 415-422. Radykalnej zmiany w widzeniu zagadnienia było nadanie przez R. Nixona w 1969 roku zagadnieniom ekologicznym rangi najważniejszego problemu ludzkości. Por. G. Manzone, Ecologia, „Rivista di Teologia Morale” 110 (1996), s. 291-301.

${ }^{9}$ Paolo VI, Messaggio di Paolo VI Le preoccupazioni ecologiche e le esigenze del reale sviluppo, w: Insegnamenti di Paolo VI, 1972, X, s. 606-609. W dokumencie papież podkreśla, że dziś dostrzega się świadomość wzajemnej zależności środowiska i człowieka. Środowisko warunkuje życie i rozwój człowieka, który ze swej strony doskonali je i nobilituje swą obecnością, pracą i kontemplacją. Jednakże zdolności twórcze człowieka przynoszą prawdziwe i trwałe owoce tylko pod warunkiem poszanowania praw podtrzymujących życie i zdolności regeneracyjne przyrody. Tak więc człowiek i natura są od siebie zależne i wspólnie dzielą swoją przyszłość.

${ }^{10}$ Por. tamże, s. 606-609.

${ }^{11}$ Ingerowanie w stworzenie - wg Pawła VI - nie powinno być równoznaczne z niszczeniem, ale doskonaleniem bez obracania go w niezamieszkały chaos, ale przyjazne i uporządkowane miejsce respektujące wszystkie tworzące go elementy. Nie można przywłaszczać sobie w sposób absolutny i egoistyczny środowiska, które nie jest res nullius, ale res omnium, 
Kilka lat później Konferencja Episkopatu Niemiec w swej deklaracji poświęconej przyszłości stworzenia i przyszłości człowieka, wychodząc z tych samych założeń, zainteresowała się relacjami i sposobami działania człowieka w odniesieniu do innych stworzeń zapewniających mu istnienie. Już na początku dokumentu biskupi stwierdzają, że człowiek ,tylko w solidarności $z$ resztą stworzenia, tylko odpowiedzialnością wobec świata zwierząt, roślin i rzeczy, może długo żyć jako pan stworzenia, nie stając się niewolnikiem swoich manii wielkości, niewolnikiem odrzuconym przez stworzenie"12. Nadszedł więc moment, w którym człowiek powinien zainicjować nowy typ relacji z istotami żywymi, z rzeczami i przestrzenią życiową, aby świat mógł być światem dla człowieka, aby człowiek mógł w nim istnieć ${ }^{13}$. $Z$ tego wynika, że świat jest dziedzictwem, które jedno pokolenie ma przekazywać następnemu; którego nie może zawłaszczyć wyłącznie dla siebie, ponieważ nie wszystkie bogactwa są odnawialne, a negatywne efekty niezrównoważonego rozwoju będą odczuwane przez następne stulecia. To nie oznacza, że człowiek powinien powstrzymać się od czerpania zysków z ziemi i tego, co ona oferuje, ponieważ (w odróżnieniu od człowieka) rośliny i zwierzęta nie posiadają nienaruszalnego indywidualnego prawa do życia. Niemniej jednak różnorodność świata roślinnego i zwierzęcego stanowi część tego dziedzictwa stworzonego, którego człowiek musi strzec właśnie ze względu na swój status władającego i częściowo również twórcy tego świata ${ }^{14}$.

dziedzictwem ludzkości, a jego posiadacze - prywatni lub publiczni - powinni regulować korzystanie z niego dla dobrze pojmowanego dobra wspólnego. Człowiek natomiast jest pierwszym i największym bogactwem, jakie ziemia posiada. Por. tamże, s. 606-609.

${ }_{12}$ Conferenza Episcopale Tedesca, Dichiarazione su „Futuro della creazione e futuro dell'umanità” (Fulda, settembre 1980), „Medicina e Morale” 2 (1990), s. 367-381.

${ }^{13}$ Inne stworzenia z pewnością istnieją po to, aby służyły człowiekowi, ale jeszcze bardziej istnieją dla racji samego istnienia. Te dwie racje wcale się wzajemnie nie wykluczają. Przeciwnie, jeżeli człowiek nie uznaje racji istnienia innych stworzeń i redukuje je do rangi zwykłego narzędzia, surowców, czy źródeł energii, to w ten sposób samego siebie pozbawia tego dobra, jakim jest świat. Człowiek musi nauczyć się panować i chronić wszystkie otaczające go stworzenia, ponieważ jest prawdą, że ,istnieją one dla człowieka, ale też człowiek żyje tylko dzięki nim". Powinien więc zaakceptować i uszanować współzależność wszystkich elementów stworzenia, zrozumieć istotę pierwszeństwa człowieka przed rzeczami, ale też nieodzowność otoczenia dla istnienia człowieka. Stąd potrzeba odpowiedzialności za świat nieożywiony rośliny i zwierzęta, ponieważ „ludzkość ma przed sobą przyszłość tylko jeżeli stworzenie ma przyszłość przed sobą. Ta wspólna przyszłość nie jest jedynie owocem naukowej i technicznej kalkulacji, ale przede wszystkim etycznej odpowiedzialności. Por. tamże.

${ }^{14}$ Nie chodzi tu o rodzaj arki Noego, w której ocali się pojedyncze egzemplarze, pozwalając zginąć wszystkim innym. Istota żywa nie musi żyć tylko dla człowieka, ale dla wyrażenia piękna i wielkości aktu stworzenia; po prostu dla samego życia i istnienia. Por. tamże.

W połowie lat osiemdziesiątych zagadnienia ekologiczne stały się częstym tematem nauczania Jana Pawła II. Niejednokrotnie podkreślał żywe zainteresowanie Kościoła katolic- 
Rosnącej uwagi Stolicy Apostolskiej skupionej na inicjatywach rozwoju i postępu całej rodziny ludzkiej nie można tłumaczyć jedynie wzajemną zależnością globalnych zagrożeń ekologicznych i koniecznością przekładania ich na działania międzynarodowe, krajowe i lokalne. Uzasadnienia szukać należy w przekonaniu, że gwarancją rozwoju i pokoju dla całej ludzkości jest sprawiedliwa dystrybucja zasobów naturalnych według dobrze opracowanych programów ekologicznych ${ }^{15}$.

kiego tym problemem, kontynuując myśli Pawła VI wyrażone w Sztokholmie w 1972. Okazją ku temu była wizyta w siedzibie Narodów Zjednoczonych w Nairobi (Centrala Programu Ochrony Środowisko ONZ (UNEP)). Panowanie nad stworzeniem papież określił jako wymóg godności ludzkiej niezbędnej dla całej rodziny ludzkiej. Por. E. Sgreccia, M. Pennacchini, M. B. Fisso, I documenti della Chiesa sulla questione ambientale, „Medicina e Morale” 4 (2000), s. 635-675.

${ }^{15}$ Nic więc dziwnego, że nauczanie Jana Paweł II było kontynuacją myśli i zamiarów Pawła VI, który w 1972 r. pisał, że prawdziwy i sprawiedliwy rozwój rodzaju ludzkiego jest gwarancją ochrony środowiska, gdyż bieda przyczynia się do jego niszczenia, o czym zresztą mówił już wcześniej w Encyklice Populorum Progressio z 1967 roku, podkreślając ścisłe zależności między rozwojem i pokojem na świecie. Jan Paweł II uznał swój „dług” wobec Populorum Progressio, pisząc: „Odnoszę się do słów Pawła VI, które stały się już bardzo znane: «Rozwój to nowe imię pokoju», bo rzeczywiście integralny rozwój jest warunkiem pokoju, a programy ekologiczne mające zapewnić żywność i mieszkania są konkretnymi sposobami promowania pokoju. Osoby przyczyniające się do zapewnienia podstawowych potrzeb innych przyczyniają się do budowania pokoju". Por. Giovanni Paolo II, I programmi ambientali per assicurare cibo e alloggio, modi concreti per promuovere la pace (18.08.1985), w: Insegnamenti di Giovanni Paolo II, 1985, vol. VIII (2), nr 4, w: http://www.vatican.va/holy_father/john_paul_ii/ speeches/1985/august/documents/hf_jp-ii_spe_19850818_centro-nazioni-unite_it.html

Uwaga poświęcona ochronie środowiska jako gwarancji sprawiedliwego rozwoju ludzkości jest przesłanką pokoju i była stałym elementem nauczania Ojca Świętego. Przykładem tego są słowa skierowane do członków Papieskiej Akademii Nauk 5.06.1986 r. „Analiza zdjęć satelitarnych może dostarczać szczegółowych i precyzyjnych danych dotyczących upraw rolniczych, łącznie z plonami lub ich stratami, możliwością użycia środków technicznych w ograniczaniu postępującej dezertyfikacji, która zagraża środkom utrzymania znacznego odsetka ludności na świecie. [...] Przy wykorzystaniu tej metody można poprawić efektywność wielu projektów, które mają na celu polepszenie warunków glebowych intensyfikujących produkcję rolną, wprowadzanie nowych upraw, zapobieganie niszczenia obszarów leśnych niezbędnych dla utrzymania równowagi ekologicznej oraz zapobieganie lub wykorzystanie panujących warunków atmosferycznych" (nr 1). Znaczenie i korzyści tych postępów technologicznych, wg Jana Pawła II, znajdują swe uzasadnienie nie tylko w pomocy człowiekowi w wykorzystywaniu zasobów naturalnych w poszanowaniu limitów stawianych przez samą przyrodę i wymagań różnych grup ludzi zamieszkujących odmienne obszary ziemi, ale przede wszystkim w fakcie, że pozwalają one, w sposób pośredni, pomóc całej rodzinie ludzkiej, aby dojść do doskonalszej „formy współistnienia na ziemi, aby istniejące na niej zasoby, które są wspólnym dziedzictwem, mogły być sprawiedliwie dzielone między wszystkich. W tym celu wyraża nadzieję, że wszystkie rządy przyczynią się do pokojowego korzystania z bogactw środowiskowych, faworyzując jednocześnie jednoczenie rodziny ludzkiej w sprawiedliwości i pokoju" (nr 3). Por. Giovanni Paolo II, L'uso pacifico dello spazio favorisce l'unificazione della 
W roku 1987, podczas spotkania z grupą naukowców Papieskiej Akademii Nauk, Jan Paweł II po raz kolejny wraca do problemu ochrony środowiska naturalnego człowieka, widząc nieodwracalne zniszczenia w sensie ilościowym i jakościowym, jakie miały miejsce w ostatnim stuleciu. Przeświadczony, że do rozwiązania licznych problemów ekologicznych nie można dojść wyłącznie poprzez zastosowanie nowoczesnych technologii, zachęca do reorientacji kultury i świadomości ogólnej, której można dokonać jedynie poprzez wychowanie proekologiczne ${ }^{16}$. Wkrótce potem, zwracając się do uczestników XXIV konferencji FAO, potwierdza znaczenie edukacji i promowania nowych schematów postępowania, będących rezultatem powszechnego wysiłku ze strony rządów, przemysłu oraz systemów wychowawczych i kształcenia wspieranych przez organizacje międzynarodowe, łącznie z FAO ${ }^{17}$. Zrozumienie, z jakim spotkały się słowa papieża, pozwoliło na rozwinięcie tematu i przeanalizowanie po raz pierwszy zagadnień związanych z biotechnologiami, zastosowanymi w sektorze rolno-spożywczym oraz ich wpływem na wyżywienie i rolnictwo światowe ${ }^{18}$.

famiglia umana, w: Insegnamenti di Giovanni Paolo II, 1986, vol. IX (1), dostęp: http://www. vatican.va/holy_father/john_paul_ii/speeches/1986/june/documents/hf_jp-ii_spe_19860620_ pont-accademia-scienze_it.html.

16 „Nieodpowiednie systemy gospodarowania i zapotrzebowanie na energię doprowadziły do naprawdę poważnych nadużyć w zasobach leśnych. [...] W krajach Trzeciego Świata [...] istnieje poważny problem niszczenia lasów w regionach tropikalnych i dezertyfikacji regionów suchych, problemy zagrażające możliwościom wyżywienia ludności. Odkrycia naukowe muszą być wykorzystywane w celu zapewnienia wysokiej produkcji ziemi w taki sposób, aby ludność miejscowa miała zapewnioną żywność i środki utrzymania bez niszczenia natury. W krajach rozwiniętych istnieje niepokojący problem odpadów w postaci gazowej, płynnej, stałej lub radioaktywnej. Nierozważne działania spowodowały zniszczenie natury. Ich niekontrolowana swoboda doprowadziła do kwaśnych deszczy, zanieczyszczenia środowiska i zatrucia mórz". Por. Giovanni Paolo II, Solo un atteggiamento di rispetto può correggere i danni provocati all'ambiente, w: Insegnamenti di Giovanni Palo II, 1987, X (3), s. 1018-1019.

${ }_{17}$ Por. Giovanni Paolo II, Allocuzione ai partecipanti della XXIV conferenza della FAO, w: Insegnamenti di Giovanni Palo II, 1987, X (3), s. 1096.

${ }^{18}$ Tak zwane nowoczesne biotechnologie, znajdując zastosowanie w różnych resortach gospodarki (medycyna, rolnictwo, przemysł spożywczy, przemysł chemiczny czy ochrona środowiska) od momentu pojawienia się są dokładnie obserwowane. W szczególności dotyczy to tych, które nastawione są na modyfikowanie dziedzictwa genetycznego istot ludzkich. Nieco inaczej traktowane są natomiast biotechnologie roślinne i zwierzęce; niosą one z sobą pewną nadzieję (jeśli nie okażą się niebezpieczne) polepszenia możliwości wyżywienia ludności na świecie, uzyskania produktów w większej ilości i jakości niż w przeszłości. Przy tej okazji Stolica Apostolska wyraziła swe poparcie dla FAO i chęć wysunięcia propozycji zasad efektywnej aplikacji genetyki roślinnej, głównie jeśli chodzi o wykorzystanie rezultatów badań naukowych, szczególnie obszarów oczekujących pomocy technicznej i naukowej. 


\section{Zaangażowanie Kościoła w promowanie ekologizmu na miarę czlowieka}

Apel o angażowanie się w zmianę mentalności poprzez edukację w celu ograniczenia degradacji środowiska został podjęty przez biskupów Lombardii, którzy w 1988 roku opublikowali tekst La questione ambientale (Problematyka ekologiczna) nastawiony właśnie na kształtowanie i wspieranie pod tym kątem świadomości chrześcijan. Zamiarem Konferencji Episkopatu Lombardii było wskazanie, że przyczyn aktualnego kryzysu ekologicznego należy się doszukiwać w kryzysie świadomości i braku akceptacji niektórych wartości etycznych, to jest w kryzysie tych zasad moralnych, które warunkują wolną wolę działania. W tym celu należy nie tylko akceptować moralnie poprawne relacje pomiędzy człowiekiem i środowiskiem oraz pobudzać zrównoważony rozwój gospodarczy, ale też wskazywać te kryteria etyczne, które powinny pomagać $\mathrm{w}$ kierowaniu ingerencjami człowieka w środowisko. Pierwszym z nich jest poszanowanie środowiska życia. Wskazuje ono na konieczność zachowania tych możliwości, które nadał człowiekowi Stwórca, i z których korzysta oddziałując na otoczenie. Środowisko naturalne to uporządkowana całość, człowiek więc winien realizować się i rozwijać tworzoną przez siebie cywilizację w oparciu o porządek Boży. Toteż każdy rodzaj interwencji i przekształcania środowiska powinien być z uwagą analizowany i oceniony w oparciu nie tylko o założenia typu ekonomicznego, ale też o możliwe zagrożenia, jakie może ono prowokować. Szacunek wobec przyrody jest więc sposobem okazywania Bogu wdzięczności, a działania ukierunkowane na ratowanie piękna środowiska naturalnego nie są dalekie od uznania ich za formę czci i kontemplacji Mądrości.

Drugim kryterium sugerowanym przez Konferencję Episkopatu Lombardii jest umiarkowanie. Wynika to z nieodnawialności wielu bogactw naturalnych, co z kolei dyktuje konieczność budowania dobra całej ludzkości i spojrzenia ze szczególną troską na kraje rozwijające się i ekonomicznie zacofane. Ekologia powinna stać się elementem składowym i symbolem solidarności międzynarodowej, rozwagi konsumpcji i dzielenia się. W tym samym dokumencie podkreślono, iż nie można zapominać o odpowiedzialności obecnych pokoleń za rozwój i przyszłość przyszłych pokoleń, którym nie można odbierać nadziei nadmiernym zużywaniem bogactw ${ }^{19}$.

19 Por. Conferenza Episkopale Lombarda, La questione ambientale (15.09.1988), Milano 1988, s. 24-27.

W swym nauczaniu Jan Paweł II, wspominając o przyszłych pokoleniach, podkreśla obowiązek moralny rozmyślnego używania dóbr natury nie tylko przez obecnie żyjących, ale również tych, którzy dopiero nadejdą. Stwierdza między innymi, że postępy w dziedzinie 
Do wspomnianych wyżej biskupi Lombardii dodają trzecie kryterium, którym jest jakość życia. Dotyczy ono nie tylko działań skierowanych na zachowanie naturalnych walorów dzikiej przyrody, ale też dalece przekształconych środowisk życia, jakimi są na przykład peryferie wielkich metropolii, obszary silnie uprzemysłowione i rolniczo wykorzystywane ${ }^{20}$.

Ścisłe zależności pomiędzy ochroną środowiska, sprawiedliwym i rozsądnym wykorzystywaniem zasobów, zrównoważonym rozwojem wszystkich krajów i pokojem światowym, zostały potwierdzone przez kardynała R. Etchegaraya, ówczesnego przewodniczącego Papieskiej Rady Iustitia et Pax w czasie europejskiego spotkania ekumenicznego, zorganizowanego przez Radę Konferencji Episkopatów Europy (CCEE) i Konferencję Kościołów Europy, które odbyło się w Bazylei (15-21.05.1989 roku). Kardynał mówił o obowiązku życia godnego stworzenia Bożego każdego wierzącego, co oznacza pakt zrozumienia i solidarności z całym stworzeniem. Dzisiaj bardziej niż kiedykolwiek w przeszłości chrześcijanin musi nauczyć się żyć, szanując wolę Boga Stworzyciela, który obdarzył go wolnością i odpowiedzialnością, to jest zdolnością odpowiedzialnego modyfikowania własnego i cudzego przeznaczenia. Bóg, stwarzając człowieka, jako jedynemu ze wszystkich stworzeń dał wolność, a więc możliwość działania i modyfikowania nawet tego, co On sam powołał do istnienia. Ale fakt, że istota ludzka jest „stworzeniem tworzącym”, implikuje w pierwszym rzędzie odpowiedzialne korzystanie $\mathrm{z}$ tej wolności nie tylko w odniesieniu do tego, czym została otoczona, ale i w stosunku do współbraci, tworząc w ten sposób gwarancje pokoju. Wyjątkowe znaczenie w umacnianiu pokoju na świecie przewodniczący Papieskiej Rady przypisuje sprawiedliwej dystrybucji wszystkich dóbr, a nie tylko samych nadwyżek. „Bogactwa natury - przypomina kardynał R. Etchegaray - są dziedzictwem ludzkości. Kto z nich korzysta, nie powinien zapominać o potrzebach innych ludzi, tych obecnie żyjących i w przyszłości”21.

ekologii, rozwój świadomości potrzeby ochrony nieodnawialnych zasobów naturalnych pozostaje w zgodzie z wymogiem słusznego panowania, ponieważ „Bóg jest uwielbiony, kiedy stworzenie wspomaga integralny rozwój całej rodziny ludzkiej” (nr 2). Por. Giovanni Paolo II, I programmi ambientali.

${ }^{20}$ Kryteria te mają znaczenie nie tylko dla zachowań społecznych i grupowych. Powinny też wpływać na decyzje indywidualne, również dlatego, że właściwie rozumiana wrażliwość ekologiczna wiernych jest też częścią chrześcijańskiego wzrastania. Wymaga ono od jednostki zrozumienia problemów ekologii i wartości z nią związanych i jeżeli jest to konieczne, również zmiany mentalności w ich postępowaniu w stosunku do przyrody. Por. Conferenza Episkopale Lombarda, dz. cyt..

${ }^{21}$ Por. R. Etchegaray, La responsabilità cristiana in un periodo di crisi, „Il RegnoDocumenti” 13 (1989), s. 18. 
Ten sam niepokój o ratowanie stworzenia przebija w głosie Konferencji Episkopatu Niemiec ${ }^{22}$. Szczególnie ważny okazuje się apel skierowany do polityków i naukowców. Od pierwszych oczekuje się nie tylko wspierania rolnictwa przemysłowego, ale i przekształceń działalności rolniczej w działalność chroniącą środowisko, towarzyszącą produkcji żywności ${ }^{23}$. Od naukowców natomiast nie tylko umiejętności wykorzystania zdobywanej wiedzy, ale i mądrości w przekształcaniu przyrody ${ }^{24}$.

Apelem skierowanym do ludzi i instytucji rządzących o zachowanie naturalnych wartości przyrodniczych była też propozycja reprezentanta Stolicy Apostolskiej na konferencji poświęconej bezpieczeństwu i współpracy w Europie (Sofia, 16.10-3.11.1989 roku). Jak stwierdził nuncjusz apostolski F. Colasuonno, każde postępowanie człowieka musi zawsze opierać się na zasadach poszanowania natury, ponieważ tylko w ten sposób wyraża się

${ }^{22} \mathrm{~W}$ dokumencie Kościoła niemieckiego (25.09.1998) poświęconym sytuacji rolnictwa wskazano, że niektóre formy intensywnego gospodarowania przyczyniają się do minowania praw natury. Mając na względzie założenia czysto praktyczne, które w pewnej mierze wymusiły interwencję biskupów, nie jest zaskoczeniem, że w liście tym podejmują problem kryzysu niemieckiego rolnictwa i ochrony stworzenia, zwracając się bezpośrednio do różnych grup społecznych i zawodowych, a więc rolników, polityków, naukowców i zwykłych obywateli.

${ }^{23}$ Wytwarzanie artykułów żywnościowych pozostaje nadal naczelną funkcją tego sektora gospodarki. Powinny temu towarzyszyć aktywne inicjatywy chroniące środowisko wiejskie, w szczególności glebę, wodę i powietrze stanowiące zabezpieczenie egzystencji całej ludzkości. W opinii Episkopatu Niemiec, w pewnym sensie również środowisko jest swego rodzaju „pokarmem”, toteż nasza ekonomiczna świadomość dzisiaj bardziej niż kiedykolwiek musi się z tym liczyć. Polityka rolna musi uwzględniać fakt, że w sytuacjach konfliktowych należy przedkładać bezpieczeństwo długoterminowe pozostające w zgodzie z naturalnymi zasadami ochrony życia nad krótkoterminowymi korzyściami ekonomicznymi, ponieważ tylko w ten sposób można uniknąć błędnych i kosztownych kierunków rozwoju obciążających przyszłe pokolenia. Por. Conferenza Episcopale Tedesca, La situazione dell'agricoltura, „Il RegnoDocumenti" 3 (1990), s. 96-99.

${ }^{24}$ Uwaga biskupów niemieckich skupiła się przede wszystkim na biotechnologiach sektora rolno-spożywczego, ale odzwierciedla znacznie większe obawy przed potencjalnymi konsekwencjami wprowadzania do środowiska organizmów genetycznie modyfikowanych i reperkusjami ekonomicznymi spowodowanymi monopolizacją rynków, aniżeli te sygnalizowane przez naukowców i moralistów końca lat osiemdziesiątych. Zdaniem biskupów, również rozwój naukowy musi znać swoje granice; ich ewentualne przekroczenie spotka się z żądaniami odpowiedzialności za całość stworzenia według kryteriów etycznych. Z jednej strony uzyskiwanie maksymalnych korzyści z działalności rolniczej byłoby wielką przysługą dla ludzkości. Z drugiej, nie można pozwolić na bezkrytyczne realizowanie kosztem środowiska tego wszystkiego, co technicznie jest możliwe przy wykorzystaniu ziemi, umiejętności uprawy roślin i hodowli zwierząt. Niekontrolowane i bezwarunkowe zastosowanie wiedzy naukowo-technicznej w rolnictwie zaostrzyłoby wciąż istniejące problemy braku równowagi pomiędzy popytem a podarzą i presję intensywnej gospodarki rolnej na środowisko. Podsumowując, biskupi Niemiec są zdania, że analiza zagadnienia zawsze powinna uwzględniać zarówno aspekty ekonomiczne, jak i ekologiczne środowiska życia. Por. tamże, s. 96-99. 
szacunek dla ludzi dnia dzisiejszego i jutrzejszego. Dlatego osoby będące u steru władzy, naukowcy i ludzie Kościoła, nie mogą unikać odpowiedzialności za decyzje mogące wiązać się z warunkami egzystencji przyszłych pokoleń. Jest to obowiązek moralny, a nie tylko wybór pomiędzy różnymi opcjami politycznymi. Dlatego osoba uchylająca się od odpowiedzialności za środowisko służące człowiekowi i jego rozwojowi bardziej niż pomyłkę popełnia grzech ${ }^{25}$.

\section{Ekologia jako „nowy” element edukacji religijnej współczesnego czlowieka w świecie}

Dbałość o środowisko przyrodnicze w krótkim czasie stała się nowym i nieodłącznym aspektem rozwoju. Potwierdził to Jan Paweł II, stwierdzając, że:

kiedy kierujemy naszą uwagę na zagadnienia ekologiczne, walka z głodem okazuje się coraz trudniejsza [...]. W zakresie ekologii widać, że w powiązaniu z procesem rozwoju, a w szczególności z potrzebami produkcji, w każdej inicjatywie ekonomicznej w pierwszym rzędzie istnieje potrzeba racjonalnego i skalkulowanego wykorzystywania zasobów naturalnych. Coraz wyraźniej dostrzega się, że bezmyślna eksploatacja dostępnych dóbr naturalnych ze szkodą dla podstawowych źródeł energii, zasobów i w ogóle środowiska naturalnego, łączy się z poważną odpowiedzialnością moralną. Podobną odpowiedzialnością będą obciążone nie tylko obecne, ale i przyszłe pokolenia ${ }^{26}$.

W tym samym klimacie utrzymane jest posłanie papieża z okazji światowego dnia pokoju na rok 1990. Dokument ten prezentuje się jako podsumowanie stanowiska Kościoła wyrażanego na forum publicznym w ciągu dwóch poprzedzających go dekad. Papież powraca do ścisłej zależności pomiędzy pokojem i poszanowaniem środowiska naturalnego, mówiąc o:

${ }^{25}$ W dalszej części wystąpienia reprezentant Stolicy Apostolskiej, zwracając się do ekonomistów i naukowców, przypomniał, że pierwsi „są powołani do odkrywania najlepszych środków opanowania rozwoju gospodarczego poprzez prowadzenie badań i rozwiązywanie problemów ekonomicznych”. Drudzy natomiast „,powinni zawsze uważać swą działalność za służbę człowiekowi i wziąć odpowiedzialność za utrzymanie środowiska w harmonii z człowiekiem”. Por. F. Colasuonno, Cura della terra dovere morale, „Il Regno-Documenti” 1 (1990), s. 6-7.

26 Wystąpienie z 16 listopada 1989 roku, wygłoszone z okazji XXV konferencji zgromadzenia generalnego FAO. Giovanni Paolo II, Aiuti ai paesi indebitati e rispetto dell'ambiente per una saggia politica alimentare internazionale (16.11.1989), w: Insegnamenti di Giovanni Palo II, 1989, XII (2), s. 1284-1285. 
Zauważalnym w ostatnim czasie wzroście świadomości, iż pokój na świecie jest zagrożony nie tylko na skutek postępującego wyścigu zbrojeń, regionalnych konfliktów i wciąż istniejącej niesprawiedliwości w obrębie poszczególnych narodów i między nacjami, ale też braku należnego poszanowania natury, bezplanowego wykorzystywania bogactw i postępującej degradacji życia. Rozwija się w ten sposób świadomość ekologiczna ${ }^{27}$, która nie może być tłamszona, lecz faworyzowana w taki sposób, aby mogła się rozwijać i dojrzewać, znajdując odpowiedni wyraz w programach i konkretnych inicjatywach ${ }^{28}$.

Ta świadomość rodzi się niezależnie od religijnego credo i jest wynikiem dostrzegania kryzysu ekologicznego jako efektu obojętności na nie do końca pojmowane, ale przecież konieczne wymogi zachowania porządku i harmonii chronionej natury. Papież zauważa, że dyscypliny tak odległe i często pozornie niewiele mające z sobą wspólnego, jak teologia, filozofia i różne gałęzie nauk technicznych, dziś bardziej niż kiedykolwiek zgadzają się z sobą co do wizji zharmonizowanego świata, posiadającego własną wewnętrzną i dynamiczną równowagę; świata, który - jeśli ma być zachowany - musi być szanowany. Człowiek oczywiście może go badać i poznawać, ale zawsze mając na względzie konieczność zachowania jego integralności. W tym wypadku szczególna rola przypada estetyce, która proponuje patrzenie na świat nie tylko pod kątem zbioru przedmiotów i narzędzi umożliwiających przetrwanie ${ }^{29}$.

Również i przy tej okazji nie można pominąć istniejących relacji pomiędzy właściwą edukacją estetyczną i utrzymaniem zdrowego środowiska ${ }^{30}$. Według papieża niektóre elementy kryzysu ekologicznego mają ewidentnie

${ }^{27}$ Pod pojęciem świadomości ekologicznej należy rozumieć przejaw formy świadomości społecznej poddanej ciągłemu kształtowaniu się i rozwojowi. Obejmuje ona również informacje dotyczące zanieczyszczenia, zagrożenia i możliwych sposobów przeciwdziałania, ale też podstawową wiedzę o zasadach zrównoważonego rozwoju cywilizacji (por. S. Kasprzak, Świadomość ekologiczna jako próg rozeznania zagrożeń środowiska naturalnego, „,Rocznik Nauk Prawnych" 1 (2000), s. 83-106). Świadomość ekologiczna zakłada odpowiednią wiedzę ekologiczną obejmującą określony zasób informacji na temat podstawowych procesów zachodzących w biosferze i w poszczególnych ekosystemach oraz mechanizmów regulujących zależności między sferą oddziaływania człowieka a środowiskiem (por. K. Fidler, Czym jest edukacja w przyrodzie, w: J. Leśniewska, J. W. Czartoszewski (red.), Edukacja w naturze, czyli jak pokochać, poznać, zrozumieć i chronić przyrodę, t. 2, Warszawa 2002, s. 33-37; M. Fiałkowski, Człowiek wobec środowiska naturalnego, „Roczniki Teologiczne” 6 (1997), s. 151-161).

${ }^{28}$ Giovanni Paolo II, Pace con Dio creatore. Pace con tutto il creato (8.12.1989), „Il Regno-Documenti” 1 (1990), s. 1-4.

${ }^{29}$ Por. B. Mondin, I valori fondamentali, Roma 1985, s. 51-67.

${ }^{30}$ Por. Giovanni Paolo II, Pace con Dio. 
charakter moralny. Największe spustoszenie - poza bezkrytycznym wdrażaniem nowości naukowych i technologicznych - powoduje brak poszanowania życia, przejawiający się w różnorakich działaniach prowadzących do degradacji środowiska. Często ratio samej produkcji przeważa nad poszanowaniem pracownika, a interesy ekonomiczne stawiane są ponad dobro człowieka.

Równie niepokojące - według Jana Pawła II - są efekty prowadzenia badań genetycznych i ich zastosowania na ludziach, roślinach i zwierzętach, tym bardziej, że brak sposobów określenia rozmiaru ewentualnych szkód wywołanych wprowadzeniem do środowiska nowych genetycznie zmodyfikowanych form życia roślinnego i zwierzęcego. Obojętność lub odrzucenie fundamentalnych norm etycznych w tej sprawie prowadzi na skraj samounicestwienia. W celu zahamowania kryzysu ekologicznego papież zaproponował przede wszystkim: a) moralną konieczność szybkiego budowania nowej solidarności ogólnoświatowej - szczególnie między krajami trzeciego świata i najsilniej rozwiniętymi - co pozwoli wyeliminować strukturalne formy biedy; b) edukację i wychowywanie ludzi do odpowiedzialności ekologicznej. To z kolei pozwoli zmodyfikować ich styl życia. A ponieważ efekty degradacji odczuwają wszyscy, edukacja ekologiczna ${ }^{31}$ wymaga zaangażowania całej społeczności międzynarodowej. Posłużyłoby to nie tylko budowaniu pokoju, ale znacznie umocniłoby go. Łącząc kwestie ekologiczne w szerszy kontekst tworzenia warunków pokojowego współistnienia na świecie, lepiej dostrzega się wartość tego, co świat nam ukazuje: przede wszystkim, że we wszechświecie istnieje pewien porządek, który musi być przestrzegany; zaraz potem to, że na osobie ludzkiej obdarzonej wolną wolą ciąży odpo-

${ }^{31}$ Edukacja ekologiczna w sensie wychowania, kształcenia i uwrażliwiania na środowisko społeczno-przyrodnicze jest dziedziną stosunkowo młodą (początek lat sześćdziesiątych). Rozwinęła się w latach siedemdziesiątych i osiemdziesiątych (por. S. Kasprzak, Normatywny wymiar ekologicznych $i$ sozologicznych idei $w$ systemie prawa państwowego i kościelnego, Lublin 2003, s. 698; J. M. Dołęga (red.), Sozologia w edukacji ekologicznej, w: J. M. Dołęga, J. Sandner (red.), Świadomość i edukacja ekologiczna, Warszawa 1998, s. 143). Można ją określić jako „ogół czynników i procesów umożliwiających ludziom: 1) poznanie przyrody, społeczeństwa i kultury z punktu widzenia wpływu tych elementów na jakość całościowo pojmowanego środowiska społeczno-przyrodniczego; 2) uczestnictwo w przekształcaniu tych elementów ich życia w zgodzie z zasadą harmonii między głównymi składowymi środowiska społeczno-przyrodniczego; 3) realizację tej zasady w indywidualnym, w miarę wszechstronnym, rozwoju własnej sprawności fizycznej i umysłowej, zainteresowań i zdolności”. Por. A. Papuziński, Edukacja ekologiczna a etyka środowiska w świetle dyskusji na temat racjonalności pedagogiki, w: W. Tyburski, Etyka środowiskowa. Teoretyczne i praktyczne implikacje, Toruń 1998, s. 53. 
wiedzialność za utrzymanie tego porządku, również ze względu na przyszłe pokolenia, ponieważ kryzys ekologiczny jest problemem moralnym ${ }^{32}$.

Wychodząc z tego założenia eksperci Papieskiej Rady Iustitia et Pax w nowej Deklaracji Un contributo cattolico al processo JPIC (Justice, Peace and Integrity of Creation $)^{33}$ wskazali, że ograniczenie zniszczeń środowiska i konsekwencji nierozważnych poczynań wymaga zaangażowania świata nauki, polityków i współpracy międzynarodowej ${ }^{34}$. U ich podstawy znajdują się jednak inicjatywy Kościoła,

ponieważ zadaniem Kościoła [...] jest przypominanie wszystkim o tej odpowiedzialności, i poczynienie kroków, aby wszyscy byli tego świadomi, oraz zaoferowanie światu podstawowych elementów służących refleksji, ponieważ problem ekologiczny w rzeczywistości jest natury religijnej i etycznej. Stworzenie jest darem Boga, który należy przyjąć z poszanowaniem jego wewnętrznych praw, które są prawami harmonii. Trzeba więc umieć zrezygnować z form rozwoju grożących tej równowadze ${ }^{35}$.

Oczywiście, Kościół popiera proces rozwoju, ale nie ocenia go jedynie przez pryzmat wartości ekonomicznych. Tej redukcjonistycznej koncepcji przeciwstawia inną, biorącą pod uwagę całą rodzinę ludzką, w której rozwój i postęp mają służyć dobrostanowi ludzi i środowiska.

Zachętę do angażowania się państw w ochronę środowiska znaleźć można również w Encyklice Centesimus annus. Odwołując się do stanowiska

32 Por. Giovanni Paolo II, Pace con Dio. Kilka dni później, przy innej okazji Jan Paweł II potwierdził wcześniejsze słowa o konieczności rozwijania edukacji ekologicznej, mówiąc że kryzys ekologiczny jest przede wszystkim problemem moralnym i że ściśle wiąże się z poszukiwaniem prawdziwego i trwałego pokoju na świecie. Kończąc podkreślił, że to, czego oczekuje się od nas wszystkich, to pogłębianie świadomości jedności rodziny ludzkiej. A konieczność solidarności w stawianiu czoła zagrożeniom wspólnego dla wszystkich środowiska daje możliwość wzmocnienia kooperacji i pokojowych relacji między państwami. Por. Giovanni Paolo II, Lo sfruttamento irrazionale dell'ambiente è una minaccia per l'intero genere umano, w: Insegnamenti di Giovanni Paolo II, 1989, XII (2), s. 1532.

${ }^{33}$ Dokument wysłany do Genewy, gdzie opracowywano projekt tekstu na Konferencję w Seulu.

${ }^{34}$ Inna forma współpracy - tym razem na poziomie ekumenicznym pomiędzy Kościołem katolickim a innymi Kościołami - w celu rozwiązania problemów związanych z ochroną człowieka i stworzenia została zasugerowana przez Papieską Radę Popierania Jedności Chrześcijan w Dyrektorium ekumenicznym (Direttorio per l'ecumenismo). Potwierdzono w nim powszechną wolę zintegrowania działań ratowania bogactw naturalnych stanowiących wspólne dziedzictwo wszystkich narodów. Por. Pontificio Consiglio per l'Unità dei Cristiani, Direttorio per l'ecumenismo (25.03.1993), „Enchiridion Vaticanum” 13 (1991-1993), s. 1293.

${ }^{35}$ Esperti del Pontificio Consiglio della Giustizia e della Pace, Un contributo cattolico al processo JPIC, „Il Regno-Documenti” 11 (1990), s. 381. 
swego poprzednika, papież twierdzi, że „u korzeni bezmyślnego niszczenia środowiska naturalnego tkwi błąd antropologiczny, niestety rozpowszechniony w naszych czasach" (nr 37) ${ }^{36}$. Człowiek odkrył w sobie umiejętność przekształcania świata własną pracą, zapominając, że jest to pierwotny dar zaoferowany mu przez Boga. Żyje w przekonaniu, iż może dysponować i decydować o wszystkim; arbitralnie podporządkowywać własnej woli. Dlatego

do obowiązków Państwa należy troska o obronę i zabezpieczenie takich dóbr zbiorowych, jak środowisko naturalne i środowisko ludzkie, których ochrony nie da się zapewnić przy pomocy zwykłych mechanizmów rynkowych. Tak jak w czasach dawnego kapitalizmu na państwie spoczywał obowiązek obrony podstawowych praw pracy, tak teraz w nowym kapitalizmie na państwie i społeczeństwie spoczywa obowiązek obrony dóbr zbiorowych, stanowiących między innymi ramy wyznaczające jedyną przestrzeń, w której człowiek może w uprawniony sposób realizować własne, indywidualne cele (CA 40).

W latach 1992-1994 uwaga Kościoła skupiła się na problemach Południa, a więc na kwestii demograficznej, dezertyfikacji znacznych obszarów ziemi i zanieczyszczeniu wód. Jedną z przyczyn tego zainteresowania była Konferencja ONZ poświęcona problemom środowiska i rozwoju (Rio de Janeiro, 1992) oraz Międzynarodowa Konferencja na temat Populacji i Rozwoju (Kair, 1994). Na krótko przedtem Konferencja Episkopatu Wielkiej Brytanii i Walii przedstawiła deklarację, w której wyraża nadzieję usunięcia przeszkód w rozwoju krajów ubogiego Południa, niedysponujących technologiami zdolnymi właściwie chronić środowisko życia. Biskupi, odrzucając sugerowaną zależność pomiędzy bumem demograficznym a degradacją przyrody, wskazują na omawiane konsekwencje wywołane ubóstwem, ponieważ presja ludności na środowisko nie może być rozważana w oderwaniu od zagrożeń wywołanych biedą ${ }^{37}$. Stwierdzili ponadto, że dysproporcja konsumpcji zasobów i eksploatacji bogactw Południa przez Północ prowokuje zniszczenia w środowisku ${ }^{38}$.

${ }^{36}$ Jan Paweł II, Encyklika Centesimus Annus, w: Encykliki, t. II, s. 461-530.

${ }^{37}$ Por. Conferenza Episcopale di Inghilterra e Galles, Dichiarazione riguardo alla Conferenza delle Nazioni Unite sull'Ambiente e lo Sviluppo. Il "Summit" della Terra (3.06.1992), „Medicina e Morale” 4 (1992), s. 784-785.

${ }^{38}$ Zagadnienie dezertyfikacji i zanieczyszczenia wody, zagrażającym życiu i zdrowiu, a nawet przetrwaniu całych narodów, znalazło się w centrum uwagi Jana Pawła II w Messaggio per la Quaresima 1993. Nie można zapominać, że przyczyną wyjaławiania gleby i zatrucia wód jest najczęściej nieświadomy tego człowiek. Kiedy dobra naturalne nie są szanowane, postępowanie takie kwalifikuje się jako niesprawiedliwe, a nawet kryminalne, ponieważ konsekwencjami tego jest ubóstwo i śmierć wielu ludzi. To oczywiste, że „anarchiczny” rozwój 
Wzrost znaczenia problematyki ekologicznej wiążącej się ze zdrowiem człowieka przyczynił się do powtórnego przeanalizowania jej przez Jana Pawła II wraz z uczestnikami konferencji poświęconej środowisku i zdrowiu $^{39}$. W przeszłości często poruszane zagadnienia zawsze stanowiły jedynie część szerszego tematu łączącego się z trudnościami rozwoju i utrzymania pokoju na świecie. Analizując różnorodność relacji łączących człowieka ze środowiskiem, zaznaczył, że współcześnie ,przeważył aspekt zdobywania i wykorzystania zasobów", co stwarza nowe zagrożenie: środowisko będące „rezerwuarem” może stać się zagrożeniem dla „środowiska-domu”"40. Szansą dla ludzkości jest łączenie nowej wiedzy z niewzruszonymi zasadami etycznymi. Wpojenie tego mechanizmu pozwoli uczynić ze środowiska miejsce do życia i źródło bogactw służące każdemu człowiekowi; będzie w stanie wyeliminować przyczyny degradacji, zapewnić właściwe warunki sanitarne i zdrowotne stosowne do wymagań małych osiedli i wielkich metropolii ${ }^{41}$.

przemysłu i zastosowanie technologii niszczących równowagę ekologiczną przyczyniły się do ogromnych zniszczeń i katastrof. Ryzykujemy pozostawienie naszym następcom w wielu częściach świata dramatu głodu i pustyni. Por. Giovanni Paolo II, Messaggio per la Quaresima 1993 (18.09.1992), w: Insegnamenti di Giovanni Paolo II, 1992, XV (2), s. 166-167.

${ }^{39}$ Por. Giovanni Paolo II, Discorso ai partecipanti al Congresso su Ambiente e Salute, w: Pontificia Academia Pro Vita, Biotecnologie animali e vegetali. Nuove frontiere e nuove responsabilità, Città del Vaticano 1999, s. 175-177. Ważne słowa z ust głowy Kościoła w kwestii ekologicznej padły również w 1993 roku z okazji przygotowań do Konferencji w Kairze. W liście do Nadif Sadik Jan Paweł mówił o implikacjach środowiskowych wzrostu populacji na świecie, przypominając, że ekologia jest przede wszystkim kwestią moralną. Por. Giovanni Paolo II, Messaggio al segretario della Conferenza de Il Cairo (18.03.1994), „Il Regno-Documenti” 9 (1994), s. 1293. Promulgowana 1995 roku encyklika Evangelium Vitae była natomiast okazją do oficjalnego dowartościowania bioetyki i jej wkładu w rozwój myśli i dialogu w kwestii ekologii i jakości życia na poziomie ekumenicznym (por. EV 27). Por. Jan Paweł II, Encyklika o wartości i nienaruszalności życia ludzkiego Evangelium vitae, w: Encykliki, t. II, s. 639-752.

${ }^{40}$ Przy tej okazji Jan Paweł II omówił również filozoficzny aspekt problemu właściwej relacji człowiek-natura. Dotąd bowiem Kościół nie odniósł się bezpośrednio do dialogu ekofilozoficznego, który różnił zwolenników antropocentryzmu i antyantropocentryzmu. Przypomina, że człowiek, dopiero od niedawna zdając sobie sprawę z rozmiarów zniszczeń, szuka czasami skrajnych wobec siebie stanowisk. Jedni, w sytuacji wyczerpywania się bogactw i zasobów naturalnych, domagają się opanowania zjawisk demograficznych w ubogich regionach świata. Inni uważają biosferę za wspólnotę biotyczną, eliminując wszelkie różnice ontologiczne i aksjologiczne pomiędzy człowiekiem i innymi istotami żyjącymi, negując tym samym istnienie odpowiedzialności człowieka za resztę stworzenia. A przecież równowaga ekosystemów i zdrowie środowiska wymagają właśnie odpowiedzialności człowieka i to odpowiedzialności otwartej na nowe formy solidarności. Por. Giovanni Paolo II, Discorso ai partecipanti.

${ }^{41}$ Por. Giovanni Paolo II, Discorso ai partecipanti.

Przyjęta przez papieża perspektywa może wydawać się nazbyt antropocentryczna, ale w rzeczywistości ten antropocentryzm okazuje się przeniknięty odpowiedzialnością za ratowanie 


\section{Ekologia dla zgłębiania prawdy o całym czlowieku}

Powraca więc kwestia potrzeby formacji indywidualnej i społecznej. Podkreślił to monsignor J-L. Tauran na Zgromadzeniu Ogólnym ONZ w dniu 27 czerwca 1997 roku, gdzie stwierdził między innymi, że:

poczynając od dzieciństwa i na początku edukacji, rodzice i wychowawcy mogą, poprzez tworzenie atmosfery, pouczenia i świadectwa, uczyć młodzież szacunku do środowiska, gospodarowania zasobami i w ten sposób prowadzić do akceptacji, dzielenia się i dawania. W tym jakże aktualnym działaniu ważną rolę spełniają wierzący. Powinni oni pomagać innym wyjść poza zwykłe poszanowanie natury i podział zasobów [...] w celu odnalezienia sensu zachwytu wobec piękna natury, która zawsze może coś powiedzieć o Tym, który nas poprzedził i który nas przewyższa ${ }^{42}$.

Rosnący niepokój wspólnoty międzynarodowej wywołany trudnościami ochrony środowiska przyrodniczego udzielił się również biskupom Stanów Zjednoczonych, którzy postanowili włączyć troskę o stworzenie do społecznej nauki Kościoła. Nie można jej traktować tylko jako opcji, ponieważ bez niej każdy program formacyjny, włączając szkolny i katechetyczny, jest niekompletny. Dodali, że „troska o ziemię nie jest jedynie sloganem na Dzień Ziemi; jest ona częścią naszej wiary. Jesteśmy powołani do chronienia ludzi i planety, przeżywając naszą wiarę w jedności z całym stworzeniem Boga. Wyzwanie to ma głębokie korzenie moralne i etyczne, które nie mogą być ignorowane"43.

Do antropocentryzmu, który implikuje odpowiedzialność wobec środowiska naturalnego, odwołują się również biskupi australijscy, przypominając, że (w wąskiej interpretacji) prawa przysługują jedynie istotom ludzkim,

stworzenia, ponieważ istnieje nieustanna interakcja pomiędzy człowiekiem a naturą. Stawianie dobra istoty ludzkiej w centrum dbałości o środowisko w rzeczywistości jest najpewniejszym sposobem ratowania biosfery. W ten sposób rozbudza się we wszystkich odpowiedzialność za bogactwa przyrody i ich rozsądne wykorzystanie. Por. Giovanni Paolo II, Messaggio per la Giornata mondiale della Pace 1999: Nel rispetto dei diritti umani il segreto della pace vera (8.12.1998), „L'Osservatore Romano” (16.12.1998) supl., nr 289.

42 J. L. Tauran, La causa dell'ambiente è la causa dell'uomo, „Medicina e Morale” 5 (1998), s. 1027.

${ }^{43}$ U. S. Bishops, Sharing Catholic social Teaching. Challenges and Directions, dostęp: http://www.nccbuscc.org/sdwp/projects/socialteaching/socialteaching.htm\#intr; E. Sgreccia, M. Pennacchini, M.B. Fisso, dz. cyt., s. 635-675. 
jako jednostkom lub jako zbiorowości, a nie innym stworzeniom. To jednak nie zwalnia z obowiązku roztoczenia nad nimi ochrony ${ }^{44}$.

Również Konferencja Episkopatu Austrii w liście skierowanym do wiernych próbowała określić warunki działania uwzględniające wymogi środowiska naturalnego, zwracając się z apelem o zaangażowanie w przeciwdziałanie degradacji środowiska życia ${ }^{45}$. Biskupi w ten sposób chcieli przypomnieć katolikom, że każdy osobiście jest odpowiedzialny za niszczenie środowiska i że każdy indywidualnie musi angażować się w przywracanie równowagi naturalnej. Duszpasterze Kościoła austriackiego, formułując swoje myśli, nie zamierzali umniejszać roli rządów i współpracy między nimi na poziomie międzynarodowym. Wspólne i skoordynowane działania narodów świata należą do priorytetów w budowie pokoju: dopóki nie wyeliminuje się biedy w krajach trzeciego świata, dopóty istnieć będą poważne zagrożenia środowiska przyrodniczego.

Analiza treści wspomnianych dokumentów i interwencji autorytatywnych instytucji Kościoła katolickiego sugeruje naglącą potrzebę metodycz-

${ }^{44}$ Por. Vescovi Australiani, Lettera pastorale Una pietra miliare per la famiglia umana, „L'Osservatore Romano” 28-29.12.1998. Tak określili swe stanowisko, dystansując się od filozofii propagującej prawa zwierząt i prawa natury w ogóle, i utwierdzając centralną pozycję człowieka we wszechświecie. Mówienie wyłącznie o prawach zwierząt, roślin czy przyszłych pokoleń znaczyłoby oddalanie się od utwierdzonej idei, że jedynie obecnie żyjący mają rzeczywiste prawa sensu stricte. To oczywiście nie oznacza, że zwierzęta mogą być maltretowane lub że można beztrosko niszczyć połacie pierwotnego lasu, albo że nie ma potrzeby zastanawiania się nad przyszłością rasy ludzkiej. Problemem dziś nie jest rzekoma dezaktualizacja antropocentryzmu, co trudności z właściwą jego interpretacją. Kościół wrażliwy na problemy ekologii uważa za niezbędne potwierdzenie centralnej roli człowieka w całości stworzenia. Ponownie proponuje człowiekowi przyjęcie tej roli stróża wszystkich stworzeń, którą w przeszłości wielu katolików, wrażliwych na problemy środowiska, już wykazywało. Potwierdzeniem tego stanowiska było też inne wystąpienia Jana Pawła II, który przypomniał o konieczności roztoczenia opieki nad bogatymi ekosystemami puszczy amazońskiej (por. Giovanni Paolo II, Esortazione apostolica post-sinodale "Ecclesia in America" (22.01.1999), nr 25, dostęp: http://www.vatican.va/holy_father/john_paul_ii/apost_exhortations/documents / hf_jp-i_exh_22011999_ecclesia-in-america_it.html (27.07.2010)), powstrzymania bezkrytycznej pogoni za dobrami materialnymi i uregulowania relacji z instytucjami ekonomicznymi. Por. Giovanni Paolo II, Affinchè il pianeta sia abitabile in futuro, occorre fermare una ricerca infinita e sfrenata di beni materali, „L'Osservatore Romano” 13.03.1999, s. 5.

45 „Odpowiedzialność za stworzenie, środowisko, stanowi część obowiązków ściśle osobistych każdej jednostki i społeczności, którą otacza. [...] również jeżeli chodzi o problem ekologiczny nie można ze wszystkim czekać na Państwo. Tu również ważna jest zasada subsydiarności [...]. Wspólnota parafialna, wspólnota lokalna, grupy społeczne i inne organizacje muszą wziąć na siebie tę odpowiedzialność". Por. Conferenza Episcopale Austriaca, L'uomo èla via della Chiesa, „Il Regno-Documenti” 19 (1990), s. 599-600. 
nego rozwijania świadomości ekologicznej swoich wiernych. To oznacza, że problematyka ochrony życia na ziemi, a w szczególności życia człowieka, ściśle związanego w swej doczesnej egzystencji ze środowiskiem przyrodniczym, nie jest obca społecznej nauce Kościoła. Istotnie, znajdujemy wiele materiałów w uchwałach synodów, które zaliczane są do prawodawstwa partykularnego. Duże znaczenie mają rozważania zagadnień ekologicznych podejmowane przez duchowieństwo, a przede wszystkim autorytatywne magisterium papieży rzymskich: Piusa XII, Pawła VI i Jana Pawła II. Zadaniem Kościoła jest między innymi szukanie wraz z wiernymi trafnych rozwiązań problemów wynikających z intensywnej działalności ludzkiej. Dotyczy to zarówno polityki, ekonomii, spraw socjalnych, ale i ochrony środowiska życia. Wynika to z potrzeby budowania dobra kolektywnego, jednostek i całej wspólnoty ludzkiej ${ }^{46}$. Zgodnie z tym realizowane są również inicjatywy kleru zmierzające do pogłębienia świadomości ekologicznej wiernych. Stąd aspekt edukacji ekologicznej jawi się dziś jako wyjątkowo ważny głównie w systemie katolickiego nauczania dzieci i młodzieży.

\section{Ecological Education in Church Documents and Canon Law (Summary)}

The environment determines the existence of man who nowadays is considered to be the main and sometimes the sole protagonist of transformations. Man connects its existence with nature, he depends upon it and at the same time he conditions its existence from its good or ill will. He possesses the tools and knowledge about the possibilities of nature's transformation and even annihilation of it which makes him occupy a unique position in the universe. Therefore, efforts to protect the environment of life must be multidirectional and coordinated. It is possible that in future modern biotechnology will be the solution for sustainable development, which provides the possibility to exercise control over economy and directs scientific research. Making any decision in this area involves the responsibility of international institutions, government, and citizens. Hence, it is important to create a situation in which the development and use of modern technologies, knowledge and skills, are in conditions which ensure maximum safety and exclude needless risk to humans and the environment of their lives.

46 Por. B. Przybylski, Człowiek, świat, Kościót, „Ateneum Kapłańskie” 62 (1970), s. $281-289$. 